\title{
OUTCOME OF TOXICITY AND MORTALITY PREDICTORS OF ALUMINUM PHOSPHIDE POISONING IN FAYOUM GOVERNORATE, EGYPT
}

\author{
Amro A. Saleh and Mohammed G. Makhlof \\ Forensic Medicine and Clinical Toxicology Department - Faculty of Medicine - Fayoum \\ University- Egypt.
}

\begin{abstract}
Background: Aluminum phosphide (celphos) is ideal solid pesticide as it is cheap, effective and easy to use, in the form of chalky white or brown tablets. It is sold in the Egyptian market under the name of Celphos $57 \%$ in the form of tablets. Phosphine has direct toxic effect on the myocardium via inhibition of cytochrome oxidase, which leads to intensive cellular damage and hence cell death. Aim of the work: is to assess aluminum phosphide toxicity in patients admitted in Fayoum general hospital, regarding their frequency, predictors of severity and the outcome of toxicity.

Methodology: This study was carried out on 60 patients admitted at Fayoum General Hospital during the period from May 2015 to April 2017. All subjects were examined for: I) sociodemographic data II) medical evaluation III) Investigation: Including arterial blood gases, Serum electrolytes ( $\mathrm{Na}$ and $\mathrm{K}$ ), random blood sugar and Electrocardiography (ECG) monitoring IV) Outcome: include survived and non-survived patients.

Results: 60 patients were enrolled in the study, 49 were males and 11 females. The commonest symptoms were hypotension, cardiogenic shock and palpitation which presented as $83 \%, 80 \%$ and $70 \%$ respectively. $10 \%$ of patients had normal ECG while 90\% had abnormal ECG findings. Metabolic acidosis was detected in $72 \%$ of patients. It was found that sinus tachycardia and ventricular fibrillation was statistically significant $(\mathrm{P}$-value $<0.05)$ with $\mathrm{ABG}$ analysis. Mode of poisoning was statistically significant with both hypotension \&palpitation, also with the outcome of poisoning, presence of cardiogenic shock and ABG analysis. This study revealed significant difference (P-value < 0.05 ) between mode of poisoning, cardiogenic shock and delay time of poisoning with the outcome of toxicity. Mortality rate was $92 \%$ and ECG dysrhythmia, metabolic acidosis and cardiogenic shock were good prognostic criteria for mortality.
\end{abstract}

Keywords: Aluminum phosphide; cardiogenic shock; Dysrhythmia; Metabolic acidosis; Outcome. Corresponding author: Amro Saleh

E-mail address: saleh222008@ gmail.com

\section{INTRODUCTION}

$\mathrm{P}$ ests have dettermental effects on the farmer's crops. One of the pesticides used is aluminum phosphide (celphos), ideal solid pesticide as it is cheap, effective and easy to use, in the form of chalky white or brown tablets; it is put on the grains for days to combat pests. Once aluminum phosphide (ALP) coalesces with water or HCL, it releases phosphine gas (Sudakin, 2005 and Hosseinian et al., 2011).

The lethal dose of ALP in a normal $70-\mathrm{kg}$ adult has been reported to be $150-500 \mathrm{mg}$ (Ranga et al., 2004 and Ferrer et al., 2009).

Phosphine has direct toxic effect on the myocardium via inhibition of cytochrome oxidase, which leads to intensive cellular damage and hence cell death (Anand et al., 2013).
Toxicity by ALP can occur either by inhalation or ingestion and symptoms may vary from mild, moderate or severe manifestations. The presenting symptoms include nausea, vomiting, headache, drowsiness, epigastric pain, retrosternal pain, dyspnea, jaundice, hepatitis and delicate hepatomegaly (Bumbrah et al., 2012). In severe exposure cardiovascular system is affected in $60-100 \%$ of patients and manifested as feeble heart sounds, and hypotension, shock, arrhythmias, myocarditis and pericarditis (Karami et al., 2013).

ECG changes incorporate sinus tachycardia, ST changes, modified T, myocardial infarction, AV block, and complete heart block (Moghaddam et al., 2016). If the patient withstands the poisoning in the first day, ECG changes will standardize 
in 10-25 days. Dangerous changes can be identified by the ECG in upwards of $50 \%$ of the patients (Akkaoui et al., 2007).

As there is no specific antidote for ALP poisoning, the main therapy is supportive care. Timing significantly affects the prognosis (Anger et al., 2000). Symptomatic patients ought to be checked in the emergency unit for something like 72 hours, getting $100 \%$ oxygen and treated for other complications (Maitai et al., 2004).

The use of coconut oil is now in research with proven results, as it contains saturated fatty acids and seems to reduce the release of PH3 in gastric acid. Also, it seems to coat the stomach mucosa and prevent $\mathrm{PH} 3$ absorption (Shadnia et al., 2005). Another promising treatment could be sweet almond oil, as it decreases ALP-induced death in rats, but its action has not been reported in human beings (Saidi et al., 2012).
Essential revival by giving fluids and inotropes are additionally prescribed. Norepinephrine, phenylephrine, dopamine, or dobutamine can be utilized to treat hypotension and constant stun. Heart arrhythmias are for the most part treated by antiarrhythmic drugs, coordinate current defibrillation, or transitory pacemaker (Gurjar et al., 2011).

Aim of the work: is to assess aluminum phosphide toxicity in patients admitted in Fayoum general hospital, regarding their frequency, predictors of severity and the outcome of toxicity. So we can prove the need of Fayoum governorate to a tertiary centre dealing with such cases.

\section{SUBJECTS AND METHODS}

Aluminum phosphide is sold in the Egyptian market under the name of Celphos $57 \%$ in the form of tablets (Figure 1) (active substance $=57 \%$ and inactive substance $=43 \%$ ).

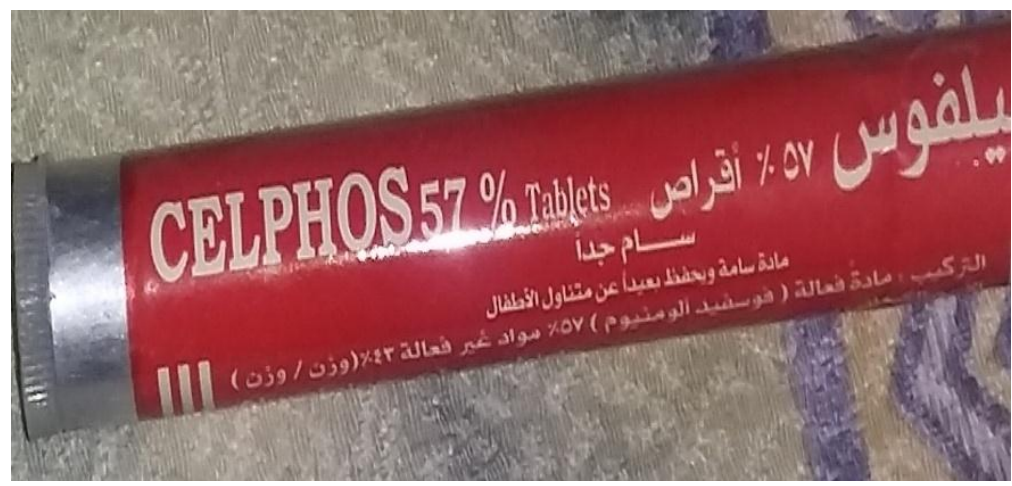

Figure (1): Aluminum phosphide package.

This study was carried out at Fayoum General Hospital during the period from May 2015 to April 2017. The cases were diagnosed as acute aluminum phosphide poisoning through accurate history taking.

The selected patients were of both sexes in different ages with acute aluminum phosphide poisoning. The diagnosis was based mainly on accurate proved history taking (seeing the package of the aluminum phosphide or accurate description of it) from cases or their neighbors about accidental, suicidal or homicidal exposure to aluminum phosphide, in addition to clinical manifestation of acute aluminum phosphide poisoning. The study was conducted on sixty patients who were presented to the hospital during the period of study.

All patients were admitted to intensive care unit (ICU) of Fayoum general hospital.

\section{Exclusion criteria}

Patients with history of other medical disorder as cardiac, pulmonary disease, liver functions disorders or renal impairment are excluded.

-In each patient, the following were studied;

A-Sociodemographic data: It included data regarding age, sex, and residence.

B-Poisoning data: It included;

- Mode of poisoning, whether suicidal, accidental or criminal.

- Number of ingested tablets (if known).

- Time passed since poisoning. C- Clinical evaluation: 


\section{Medical history:}

It included special habits of medical importance and presence of medical or psychiatric diseases.

* Physical Examination:

Examination of the patients were carried out at the time of presentation to the Fayoum general hospital regarding general examination and systemic examination for respiratory, cardiovascular, CNS and gastrointestinal systems.

\section{D-Investigation parameters:}

\section{I-Laboratory investigations:}

The laboratory work of the study was conducted at the laboratory of Fayoum general hospital

-One milliliter of arterial blood was freshly drawn from femoral artery or radial artery for immediate blood gas analysis using Rapid lab 855 of Bayer Company.

-Five milliliters of venous blood were collected from every patient on admission by using sterile plastic syringes. The samples were used for estimation of the following parameters:
- Random blood sugar was determined by colorimetric method using glucose oxidase to catalyse oxidation of glucose to gluconic acid measured by spectrophotometer at wave length $505 \mathrm{~nm}$. Normal range of glucose is 72$144 \mathrm{mg} / \mathrm{dl}$ in $37{ }^{\circ} \mathrm{C}$ (Raba and Mottola., 1995).

- Serum electrolytes ( $\mathrm{Na}$ and $\mathrm{K}$ ) were determined by ion selective electrode technique using easylyte analyzer Chairon model. Normal range of $\mathrm{Na}$ is $135-150 \mathrm{mEq} / \mathrm{L}$ and normal range of $\mathrm{K}$ is $3.5-5 \mathrm{mEq} / \mathrm{L}$ in 37 ${ }^{\circ} \mathrm{C}$ (Burnett et al., 2000).

- AST and ALT were performed using enzymelinked immunosorbent assay (ELISA) technique (Microplate reader, Biotech, USA).

II. Electrocardiogram (ECG): Electrocardiographic recording was done for every patient on admission then repeated when needed using FuKuda denstti Cardimex (model Fx-2111, Japan).

E- Patient's outcome

(A) Survived patients.

(B) Non- survived patients.

\section{RESULTS}

Table 1: Sociodemographic data of acute aluminum phosphide (ALP) poisoned patients in Fayoum General Hospital during the period from May 2015 to April 2017.

\begin{tabular}{|l|l|l|l|}
\hline \multirow{2}{*}{ Sex } & & N & $\%$ \\
\hline \multirow{2}{*}{ Mode } & Male & 49 & $82 \%$ \\
\cline { 2 - 4 } & Female & 11 & $18 \%$ \\
\hline & Suicidal & 48 & $80 \%$ \\
\cline { 2 - 4 } & Accidental & 12 & $20 \%$ \\
\hline Amount & \multicolumn{2}{|c|}{ Mean \pm SD } \\
\hline Age (years) & $1.868 \pm .7649$ & \multicolumn{2}{|}{} \\
\hline Delay time (hours) & $21.70 \pm 11.405$ & & \\
\hline
\end{tabular}

$\mathrm{N}=$ number $\%=$ percent $\quad \mathrm{SD}=$ standard deviation.

60 patients were enrolled in the study, 49 were males and 11 females. Mean age was 21.70, mode of poisoning either suicidal $(80 \%)$, or accidentally $(20 \%)$, mean amount taken was (1.868 tablet) and mean delay time (4.892 h) as seen in (Table 1). 
Table (2): Physical examination of acute aluminum phosphide (ALP) poisoned patients in Fayoum

General Hospital during the period from May 2015 to April 2017.

\begin{tabular}{|c|c|c|c|}
\hline \multicolumn{2}{|c|}{ Physical examination } & $\mathbf{N}$ & $\%$ \\
\hline \multirow[t]{2}{*}{ Vomiting } & Yes & 20 & 33 \\
\hline & No & 40 & 67 \\
\hline \multirow{2}{*}{ Abdominal pain } & Yes & 14 & 23 \\
\hline & No & 46 & 77 \\
\hline \multirow[t]{2}{*}{ Chest pain } & Yes & 17 & 28 \\
\hline & No & 43 & 72 \\
\hline \multirow[t]{2}{*}{ Dyspnea } & Yes & 23 & 38 \\
\hline & No & 37 & 62 \\
\hline \multirow[t]{2}{*}{ Headache } & Yes & 14 & 23 \\
\hline & No & 46 & 77 \\
\hline \multirow[t]{2}{*}{ Froth from mouth } & Yes & 17 & 28 \\
\hline & No & 43 & 72 \\
\hline \multirow{2}{*}{ Hypotension } & Yes & 50 & 83 \\
\hline & $\mathrm{No}$ & 10 & 17 \\
\hline \multirow[t]{2}{*}{ Palpitation } & Yes & 42 & 70 \\
\hline & No & 18 & 30 \\
\hline \multirow[t]{2}{*}{ Tremors } & Yes & 6 & 10 \\
\hline & No & 54 & 90 \\
\hline \multirow[t]{2}{*}{ Convulsion } & Yes & 4 & 7 \\
\hline & No & 56 & 93 \\
\hline \multirow[t]{2}{*}{ Cardiogenic shock } & Yes & 48 & 80 \\
\hline & No & 12 & 20 \\
\hline
\end{tabular}

$\mathrm{N}=$ number $\%=$ Percent .

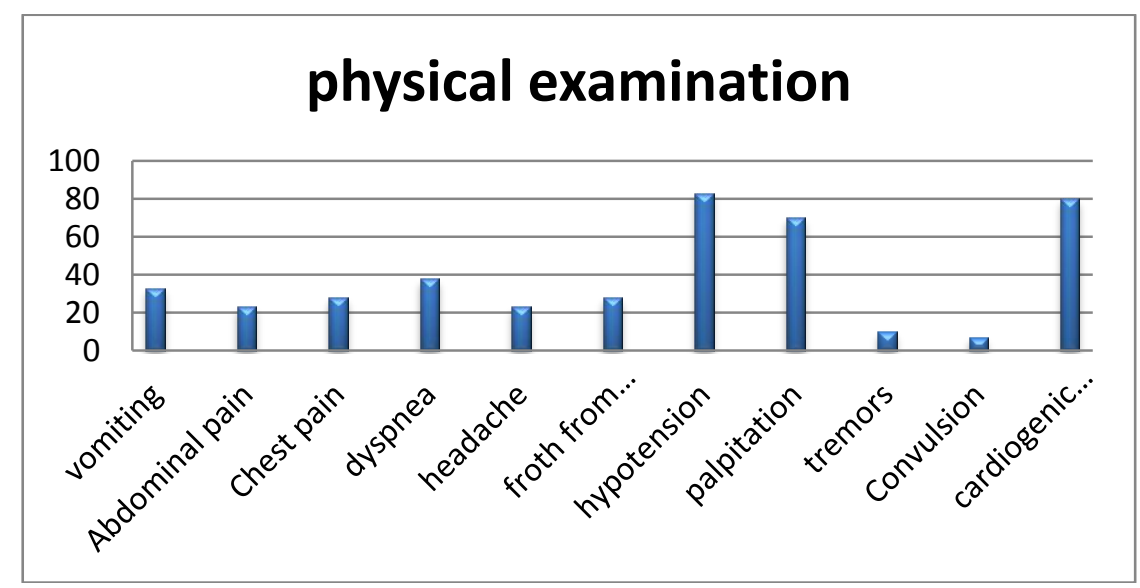

Figure (2): Physical examination of acute aluminum phosphide (ALP) poisoned patients in Fayoum General Hospital during the period from May 2015 to April 2017.

Table (2) and figure (2) showed that the commonest symptoms were hypotension, cardiogenic shock and palpitation which presented as $83 \%, 80 \%$ and $70 \%$ respectively, followed by dyspnea and vomiting which presented as $38 \%$ and $33 \%$ respectively.
Other symptoms include abdominal pain, chest pain, headache, froth from mouth, tremors and convulsions which were presented as $23 \%, 28 \%, 23 \%, 28 \%, 10 \%$ and $7 \%$ respectively. 
Table (3): Investigations of acute aluminum phosphide (ALP) poisoned patients in Fayoum General Hospital during the period from May 2015 to April 2017.

\begin{tabular}{|c|c|c|c|}
\hline \multicolumn{4}{|l|}{ Investigations } \\
\hline \multirow[t]{7}{*}{ ECG } & & $\mathrm{N}$ & $\%$ \\
\hline & Normal & 6 & $10 \%$ \\
\hline & Sinus tachycardia & 28 & $47 \%$ \\
\hline & Ventricular extra systole & 8 & $13 \%$ \\
\hline & Ventricular fibrillation & 9 & $15 \%$ \\
\hline & Complete heart block & 3 & $5 \%$ \\
\hline & Asystole & 6 & $10 \%$ \\
\hline \multirow[t]{3}{*}{$\mathrm{ABG}$} & Normal & 17 & $28 \%$ \\
\hline & Metabolic acidosis & 43 & $72 \%$ \\
\hline & \multicolumn{3}{|c|}{ Mean \pm SD } \\
\hline \multirow[t]{2}{*}{ Serum electrolytes } & $\mathrm{Na}$ & \multicolumn{2}{|c|}{$137.78 \pm 4.819$} \\
\hline & $\mathrm{K}$ & \multicolumn{2}{|c|}{$3.397 \pm .8023$} \\
\hline \multirow[t]{2}{*}{ Liver functions } & $\mathrm{AST}$ & \multicolumn{2}{|c|}{$18.58 \pm 8.484$} \\
\hline & ALT & \multicolumn{2}{|c|}{$17.20 \pm 6.45$} \\
\hline Random Blood sugar & & \multicolumn{2}{|c|}{$82.346 \pm 7.219$} \\
\hline
\end{tabular}

$\mathrm{N}=$ number $\quad \%=$ Percent $\quad \mathrm{SD}=$ standard deviation.

Regarding the investigations done to the studied patients Table (3) showed that $10 \%$ of patients had normal ECG while $90 \%$ had abnormal ECG findings; these abnormalities were presented as sinus tachycardia (47\%), ventricular extra systole (13\%), ventricular fibrillation (15\%), complete heart block (5\%) and asystole (10\%). Metabolic acidosis was detected in $72 \%$ of patients. Other investigations done were within normal range.

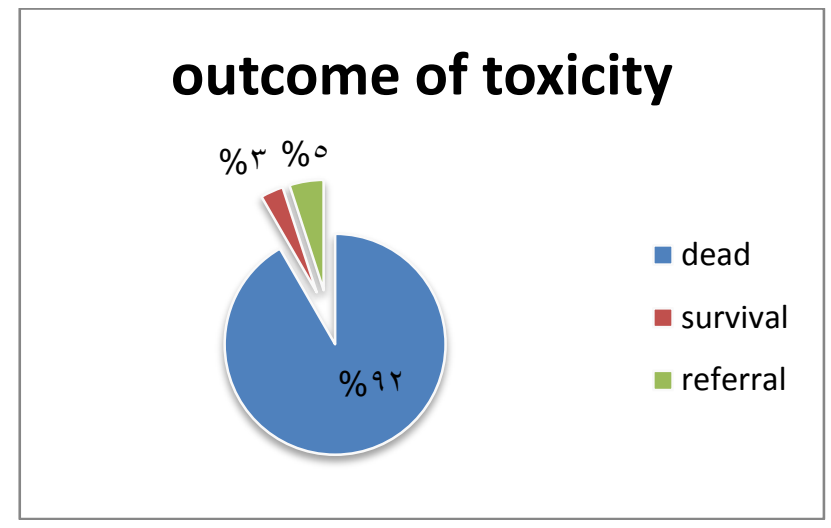

Figure (3): outcome of toxicity of acute aluminum phosphide (ALP) poisoned patients in Fayoum General Hospital during the period from May 2015 to April 2017.

As shown from figure (3), 92\% of the patients have died, 5\% was referred and only two patients have survived. 
Table (4): Relation of ECG with age, amount and ABG of acute aluminum phosphide (ALP) poisoned patients in Fayoum General Hospital during the period from May 2015 to April 2017.

\begin{tabular}{|c|c|c|c|c|c|c|c|}
\hline ECG & \multicolumn{2}{|c|}{ Age } & \multicolumn{2}{|c|}{ Amount } & \multicolumn{3}{|c|}{$\mathrm{ABG}$} \\
\hline & Mean \pm SD & $\mathrm{P}$ value * & Mean \pm SD & $\begin{array}{c}\mathrm{P} \text { value } \\
*\end{array}$ & $\begin{array}{c}\text { Normal } \\
\mathrm{N}(\%)\end{array}$ & $\begin{array}{c}\text { Metabolic } \\
\text { acidosis } \\
\mathrm{N}(\%)\end{array}$ & $\mathrm{P}$ value $* *$ \\
\hline normal & $21.17 \pm 4.665$ & \multirow[t]{6}{*}{0.880} & $1.500 \pm .8367$ & \multirow[t]{6}{*}{0.177} & $3(50 \%)$ & $3(50 \%)$ & 0087 \\
\hline S.T & $20.89 \pm 7.724$ & & $2.107 \pm .7373$ & & $4(14 \%)$ & $24(86 \%)$ & $<0.05(\mathbf{S})$ \\
\hline V.E & $25.75 \pm 12.487$ & & $1.714 \pm .7559$ & & $2(25 \%)$ & $6(75 \%)$ & 0066 \\
\hline V.F & $18.78 \pm 10.269$ & & $1.889 \pm .7407$ & & $3(33 \%)$ & $6(67 \%)$ & $<0.05(\mathrm{~S})$ \\
\hline H.B & $29.67 \pm 25.403$ & & $1.500 \pm .7071$ & & $2(67 \%)$ & $1(33 \%)$ & 0058 \\
\hline asystole & $21.00 \pm 21.485$ & & $1.300 \pm .6708$ & & $3(50 \%)$ & $3(50 \%)$ & 0078 \\
\hline
\end{tabular}

S.T $=$ sinus tachycardia $\quad$ V.E=ventricular extrasystole

V.F=ventricular fibrillation

H.B $=$ complete heart block *ANOVA test was done, Posthoc test showed difference between type sinus tachycardia \&asystole in amount $\quad * *$ Fisher Exact test was done $\quad(\mathbf{S})$ : significant. $\mathrm{N}=$ number $\quad \%=$ Percent $\mathrm{SD}=$ standard deviation.

Table (5): Student's t-test for the relation of ECG with age, amount and ABG of acute aluminum phosphide (ALP) poisoned patients in Fayoum General Hospital during the period from May 2015 to April 2017.

\begin{tabular}{|c|c|c|c|c|c|c|c|}
\hline & \multicolumn{2}{|c|}{ Age } & \multicolumn{2}{|c|}{$\begin{array}{c}\text { Amount (number of } \\
\text { tablets) }\end{array}$} & \multicolumn{3}{|c|}{$\mathrm{ABG}$} \\
\hline ECG & Mean \pm SD & $\mathrm{P}$-value * & Mean \pm SD & $\mathrm{P}$-value * & $\begin{array}{l}\text { Normal } \\
\mathrm{N}(\%)\end{array}$ & \begin{tabular}{|c} 
Metabolic \\
acidosis \\
$\mathrm{N}(\%)$
\end{tabular} & $\begin{array}{c}\mathrm{P} \text { - value } \\
*\end{array}$ \\
\hline Normal & $21.17 \pm 4.665$ & \multirow[t]{2}{*}{0.764} & $1.500 \pm .8367$ & \multirow[t]{2}{*}{0.152} & $3(50 \%)$ & $3(50 \%)$ & \multirow{2}{*}{$\begin{array}{c}<0.05 \\
(\mathbf{S})\end{array}$} \\
\hline Abnormal & $21.76 \pm 11.946$ & & $1.912 \pm .7530$ & & $14(26 \%)$ & $40(74 \%)$ & \\
\hline
\end{tabular}

* Student's t-test was done. $\quad(\mathrm{S})$ : significant $\quad \mathrm{N}=$ number $\quad \%=$ Percent $\quad \mathrm{SD}=$ standard deviation.

Regarding relation of ECG changes and other variables it was found that sinus tachycardia and ventricular fibrillation was statistically significant $(\mathrm{P}$-value $<0.05)$ with $\mathrm{ABG}$ while other variables such as age and amount are irrelevant with ECG changes, also ventricular extrasystole, heart block and asystole are statistically irrelevant even with ABG. The results showed also that most patients with abnormal ECG had metabolic acidosis as shown from (table 4 and 5). 
Table (6): Chi square statistical analysis for the relation of the mode of poisoning with sex and clinical findings of acute aluminum phosphide (ALP) poisoned patients in Fayoum General Hospital during the period from May 2015 to April 2017.

\begin{tabular}{|c|c|c|c|c|c|}
\hline & \multicolumn{2}{|c|}{ Suicidal } & \multicolumn{2}{c|}{ Accidental } & P- value \\
\hline & $\mathrm{N}$ & $\%$ & $\mathrm{~N}$ & $\%$ & $<0.001(\mathbf{H S})$ \\
\hline Male Sex & 47 & $(98 \%)$ & 2 & $(17 \%)$ & 1 \\
\hline Vomiting & 16 & $(33 \%)$ & 4 & $(33 \%)$ & 0.448 \\
\hline Abdominal pain & 10 & $(21 \%)$ & 4 & $(33 \%)$ & 0.151 \\
\hline Chest pain & 16 & $(33 \%)$ & 1 & $(8 \%)$ & 0.340 \\
\hline dyspnea & 20 & $(42 \%)$ & 3 & $(25 \%)$ & 0.712 \\
\hline headache & 12 & $(25 \%)$ & 2 & $(17 \%)$ & 0.293 \\
\hline froth & 12 & $(25 \%)$ & 5 & $(42 \%)$ & $<0.05(\mathbf{S})$ \\
\hline hypotension & 43 & $(90 \%)$ & 7 & $(58 \%)$ & $<0.05(\mathbf{S})$ \\
\hline Palpitation & 38 & $(79 \%)$ & 4 & $(33 \%)$ & 0.333 \\
\hline tremors & 6 & $(12 \%)$ & 0 & $(.0 \%)$ & 0.99 \\
\hline convulsion & 3 & $(6 \%)$ & 1 & $(8 \%)$ & \\
\hline
\end{tabular}

(S): significant (HS): highly significant

$\mathrm{N}=$ number

$\%=$ Percent

Regarding the relation of symptoms and mode of poisoning there was a statistically significant difference $(\mathrm{P}$-value $<0.05)$ between mode of poisoning and both hypotension \&palpitation, where most of suicidal patients had hypotension and palpitation. Also sex showed a highly statistical significant difference (P-value <0.001) regarding mode of poisoning, while other symptoms (vomiting, abdominal pain, chest pain, dyspnea, headache, froth, tremors and convulsions are statistically irrelevant, as shown from (table 6).

Table (7): Chi square statistical analysis for the relation of the mode of poisoning with other variables of acute aluminum phosphide (ALP) poisoned patients in Fayoum General Hospital during the period from May 2015 to April 2017.

\begin{tabular}{|c|c|c|c|c|c|}
\hline & & \multicolumn{3}{|c|}{ Mode } & \multirow[t]{2}{*}{ P-value } \\
\hline & & & Suicidal & Accidental & \\
\hline \multirow[t]{4}{*}{ outcome } & \multirow[t]{2}{*}{ dead } & $\mathrm{N}$ & 46 & 9 & \multirow[t]{4}{*}{$<0.05(\mathbf{S})$} \\
\hline & & $\%$ & $96 \%$ & $75 \%$ & \\
\hline & \multirow{2}{*}{$\begin{array}{c}\text { Referral or } \\
\text { survival }\end{array}$} & $\mathrm{N}$ & 2 & 3 & \\
\hline & & $\%$ & $4 \%$ & $25 \%$ & \\
\hline \multirow[t]{4}{*}{ Shock } & \multirow[t]{2}{*}{ yes } & $\mathrm{N}$ & 41 & 7 & \multirow[t]{4}{*}{$<0.05(\mathrm{~S})$} \\
\hline & & $\%$ & $85 \%$ & $58 \%$ & \\
\hline & \multirow[t]{2}{*}{ no } & $\mathrm{N}$ & 7 & 5 & \\
\hline & & $\%$ & $15 \%$ & $42 \%$ & \\
\hline \multirow[t]{4}{*}{ ABG } & \multirow[t]{2}{*}{ normal } & $\mathrm{N}$ & 8 & 9 & \multirow[t]{4}{*}{$<0.05(\mathrm{~S})$} \\
\hline & & $\%$ & $17 \%$ & $75 \%$ & \\
\hline & \multirow{2}{*}{$\begin{array}{l}\text { Metabolic } \\
\text { acidosis }\end{array}$} & $\mathrm{N}$ & 40 & 3 & \\
\hline & & $\%$ & $83 \%$ & $25 \%$ & \\
\hline
\end{tabular}

Table (7) showed that there was a statistically significant difference (P-value $<0.05)$ between mode of poisoning and the outcome of poisoning, presence of cardiogenic shock and $\mathrm{ABG}$ analysis, where almost all suicidal patients had cardiogenic shock, metabolic acidosis and died. 
Table (8): Student's t-test for the relation of cardiogenic shock with other variables of acute aluminum phosphide (ALP) poisoned patients in Fayoum General Hospital during the period from May 2015 to April 2017.

\begin{tabular}{|c|c|c|c|c|}
\hline variable & \multicolumn{3}{|c|}{ Cardiogenic shock } & \\
\hline & & Yes & No & P-value $^{*}$ \\
\hline age & Mean \pm SD & $20.86 \pm 10.758$ & $23.82 \pm 13.006$ & 0.369 \\
\hline delay time & Mean \pm SD & $5.088 \pm 2.4809$ & $4.055 \pm 5.5459$ & $<0.05(\mathbf{S})$ \\
\hline amount & Mean \pm SD & $2.976 \pm .7496$ & $1.594 \pm .7576$ & $<0.05(\mathbf{S})$ \\
\hline
\end{tabular}

* Student's t-test

(S): significant

$\mathrm{SD}=$ standard deviation.

Table (8) showed that there was a statistically significant difference (P-value $<0.05)$ between Delay time and amount taken with cardiogenic shock as, when the patient take a large amount of the poison and has a delay in going to the hospital, $\mathrm{He}$ will have a cardiogenic shock.

Table (9): Relation of outcome of toxicity with other variables of acute aluminum phosphide (ALP) poisoned patients in Fayoum General Hospital during the period from May 2015 to April 2017.

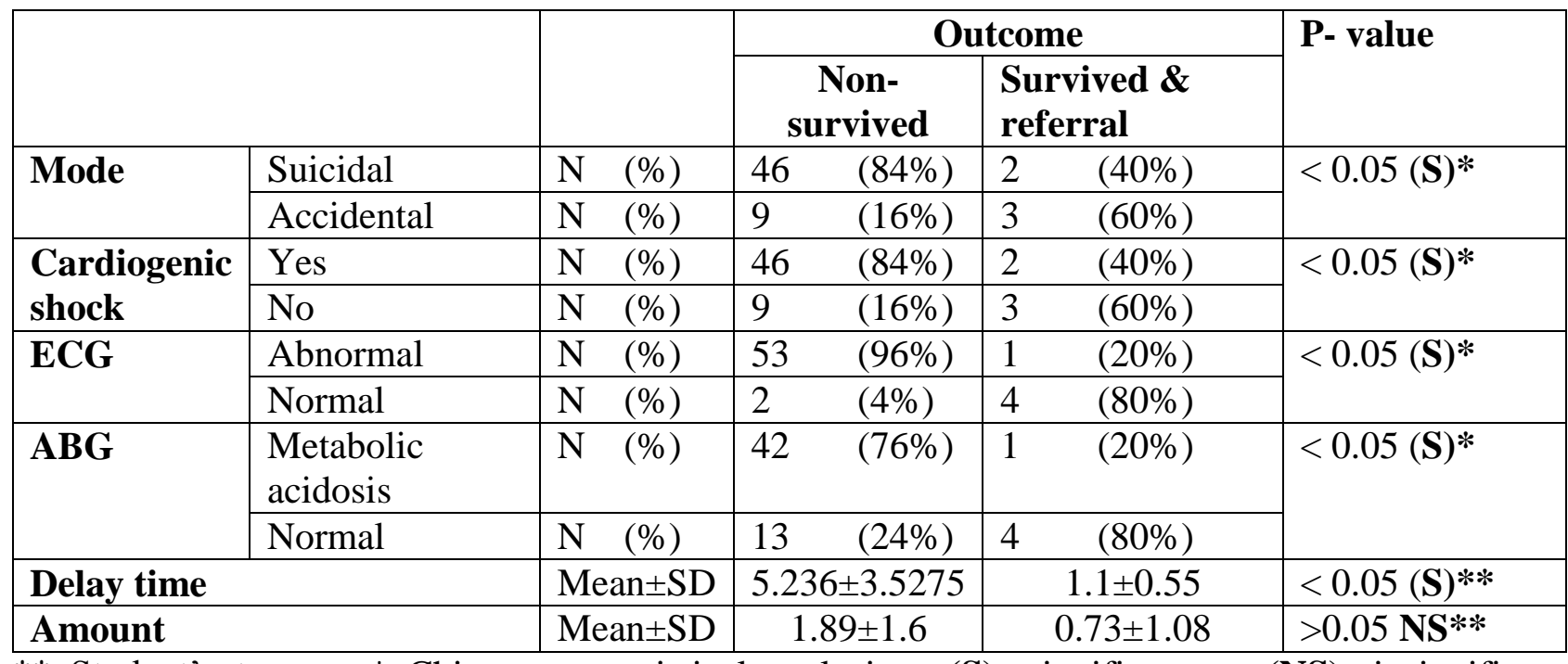

** Student's t-test * Chi square statistical analysis (S): significant (NS): insignificant difference $\mathrm{N}=$ number $\quad \%=$ Percent

Table (9) showed that there was a statistically significant difference (P-value $<0.05$ ) between mode of poisoning, cardiogenic shock and delay time of poisoning, ECG findings and $\mathrm{ABG}$ analysis with the outcome of toxicity as, died patient had suicidal toxicity, delayed in coming to the hospital and presented by cardiogenic shock, ECG dysrhythmias and metabolic acidosis. On the other hand the amount of ingested tablets was insignificant to the outcome of toxicity.

\section{DISCUSSION}

Aluminum phosphide poisoning is a typical method of suicide in the horticultural network. It has right now stimulated enthusiasm with expanding number of cases in the previous four decades because of expanded use in rural and non-farming reason, and furthermore its simple 
accessibility has expanded its abuse to submit suicide (Bajpai., 2010).

Aluminum phosphide is sold in the Egyptian market under the name celphos. It is cheap, easily available and present in any small supermarket in any small village in Fayoum governorate. It is known between the public by the name licorice poison or wheatgrass tablets.

The current study showed that, most of the victims were young (mean age $=21.7$ years) with males more than females (49 males and 11 females). Suicide among the younger is commoner than accidental poisoning (80\% suicidal and $20 \%$ accidental). The equivalent was found by Kalawat et al., 2016 and Mathai \& Bhanu., 2010, who revealed in their investigation that the dominant part of patients were youthful and in the age assemble from 21 to 40 years and the greater part of the cases included were because of self-destructive utilization of the toxic substance $(92 \%)$.

The delay time of poisoning in the current study was $4.89 \mathrm{hrs}$, which was slightly higher than what was found by Mathai \& Bhanu, 2010 in their study. The mean number of tablets used was 1.86 tablets which were the same to what were recorded by Erfantalab et al., 2017.

The commonest presentations in the current study were hypotension, cardiogenic shock and palpitation which presented as $83 \%, 80 \%$ and $70 \%$ respectively. This was in accordance with Mathai \& Bhanu., 2010, who stated that $81 \%$ of patients had cardiac symptoms, mainly in the form of hypotension and/or arrhythmias on admission to the hospital. Also Taromsari et al., 2011 reported that $83.3 \%$ of the admitted patients had initial BP $\leq$ $90 \mathrm{mmHg}$. While it was opposite with those found by Kalawat et al., 2016 who reported that the commonest presentations were Vomiting (100\% cases) and abdominal pain (70\% cases).

ECG findings were abnormal in $90 \%$ of patients as shown in this study. This was in accordance with those found by Kalawat et al., 2016 who found that ECG was abnormal in 30 cases out of 50, Taromsari et al., 2011 who reported that Arrhythmia at ECG was recorded in $75.5 \%$ of individuals. Also the same result was found by Mathai \& Bhanu., 2010. Contrary to these results Erfantalab et al., 2017 reported that about $62 \%$ of patients had normal ECG findings.

The present study revealed that the ECG abnormalities were sinus tachycardia, ventricular extra systole, ventricular fibrillation, complete heart block, and asystole which presented as $47 \%, 13 \%, 15 \%, 5 \%$, and $10 \%$ respectively. These results correlated well with Kalawat et al., 2016 who reported that Various ECG Changes were sinus tachycardia in 12 cases $(24 \%)$, sinus bradycardia in 6 cases (12\%), ventricular premature beat in 5 cases $(10 \%)$ and heart block was seen in 2 cases (4\%). In the study done by Umair Aziz\& Amir Husain 2015, they discovered Tachycardia was recognized in $68 \%$ of patients and bradycardia in $12 \%$ of patients. Eighty patients created cardiovascular arrhythmia. The most continuous arrhythmia was atrial fibrillation $(31 \%)$ trailed by ventricular fibrillation (20\%), ventricular tachycardia $(17 \%)$, third degree AV block (7\%) and second degree AV block (5\%), this was as per the current study.

Random blood sugar, serum electrolytes ( $\mathrm{Na}$ and $\mathrm{K}$ ) and liver functions (AST and ALT) measured in this study were within normal unlike the results found by Mathai $\&$ Bhanu., 2010, this difference may be due to the difference in the presenting symptoms or the number of the studied patients or timing of taking the sample.

Arterial blood gases (ABG) analysis, reported that metabolic acidosis was detected in $72 \%$ of the patients in the current study. Findings of this study correlates well with Kalawat et al., 2016 who reported metabolic acidosis in $66 \%$ of patients.

The current study has shown a significant relation (P-value < 0.05) between ECG abnormality and presence of metabolic acidosis, where $74 \%$ of patients with abnormal ECG findings had metabolic acidosis. On the other hand this relation was insignificant with number of ingested tablets and age of the patients. Same results were found by Kalawat et al., 2016.

Taromsari et al., 2011 has concurred with our outcomes as they expressed that, arrhythmia was seen in $88.2 \%$ of patients with 
starting $\mathrm{BP} \leq 90 \mathrm{mmHg}$, while this figure essentially diminished and the rate achieved $11.8 \%$ in patients with introductory $\mathrm{BP}$ in excess of $90 \mathrm{mmHg}(\mathrm{P}<0.01)$. Then again they couldn't help contradicting our discoveries as they revealed in their examination that the rate of arrhythmia among people more than 45 was $88.9 \%$. Arrhythmia was distinguished in $56.9 \%$ of the patients that had expended $\leq 1$ tablet and $43.1 \%$ of these patients have had no arrhythmia, while this rate fundamentally expanded in patients that had devoured in excess of one tablet, and it was identified in $94.1 \%$ of them $(\mathrm{P}<0.01)$.

Our study has detected a significant relation (P-value < 0.05) between mode of ingestion of ALP and presence of cardiogenic shock and metabolic acidosis, most patients with suicidal intake suffered cardiogenic shock and metabolic acidosis, this was in accordance with Kalawat et al., 2016, although he stated that presentation has not changed significantly with passage of time. Also presence of cardiogenic shock had a significant relation (P-value $<0.05$ ) with the delay time of poisoning and number of ingested tablets; this was in accordance with

\section{Mathai \& Bhanu., 2010.}

Cardiovascular toxicity because of ALP and phosphine presentation is spoken to by a depression in myocardial cellular metabolism, and myocardial necrosis because of the arrival of receptive oxygen intermediates. Without a doubt, noteworthy declines in glutathione fixations were appeared in changed tissues amid AP poisoning (Hsu et al., 2002).

Regarding the outcome of this study, it revealed that $92 \%$ of the studied patients had died $(n=55)$, while only two patients $(3 \%)$ has survived and three patients $(5 \%)$ has referred to a tertiary centre. The survived patients had come to the hospital within few minutes after ingestion, so when gastric lavage done the tablets came out of the stomach as such and before absorption.

The outcome of toxicity had a significant relation (P-value < 0.05) with mode of poisoning, delay time and presence of cardiogenic shock, but not significant with number of ingested tablets.
In agreement with our results, several studies revealed high mortality rate, although their number was lower than ours, Singh et al., $198573 \%$ mortality, Sepaha et al., 1985 85\% mortality, Ram \& Shrivastava., 1988, 72\% mortality and Chugh et al., 1991 who reported $66 \%$ mortality in their studies. Contrary to our study, Kalawat et al., 2016 reported lower mortality rate than us, where they reported in their study on 50 cases, that $38 \%$ of patients died and $61 \%$ were survived.

Our study revealed that long time before admission in the hospital, cardiogenic shock, metabolic acidosis and presence of arrhythmias in ECG are all bad prognostic criteria and can predict mortality of the patients. The treatment used in our study included ordinary gastric lavage with tape water and supportive treatment for any complication had occurred, this all didn't affect the outcome of patients. Despite all intensive medical care efforts in supportive therapy, the prognosis of ALP poisoning was bad so the use and availability of aluminum phosphide should be restricted as much as possible.

In conflict with our outcomes Mathai and Bhanu., 2010 announced in their study a lower death rate $60 \%$. Additionally they expressed that, there was no critical relationship between the portion of toxin devoured or the time delay in introduction to the clinic with mortality. Then again they concur with our outcomes in detailing the terrible prognostic criteria, where they expressed that elevated serum creatinine, metabolic acidosis, a low APACHE II score and cardiogenic shock are factors that can be evaluated at admission to the healing facility to foresee mortality from aluminum phosphide ingestion. Likewise Louriz et al., 2009 inferred that the prognostic elements related with mortality from ALP poisoning, incorporated a low APACHE II score, low grade coma, shock, ECG abnormalities, the presence of acute renal failure, low prothrombin rate, hyperleukocytosis, utilization of vasoactive medications and utilization of mechanical ventilation.

Contrary to our results Mohajeri et al., 2013 reported in their study that, ECG changes was found in just $45 \%$ of patients, 
but they were in accordance with our results in that cardiogenic shock and myocardial affection are major cause of death.

Erfantalab et al., 2017 announced a lower death rate $(38.5 \%)$ than ours. Then again they concurred with our results in regards to the awful prognostic criteria for mortality, they uncovered that ECG variation from the norm, cardiogenic shock and metabolic acidosis were essentially extraordinary between the survivors and nonsurvivors gatherings. Likewise Taromsari et al., 2011 expressed that Arrhythmia was shown in the ECG of the $91.7 \%$ of the dead patients, though none of the released patients had arrhythmia $(\mathrm{P}<0.01)$.

Advancement of refractory shock, ARDS, aspiration pneumonitis, anemia, metabolic acidosis, electrolyte imbalance, coma, severe hypoxia, gastrointestinal bleeding, and pericarditis were the variables supposedly connected with poor forecast (Wahab et al., 2008).

Death of patients in the current study had occurred in the $1^{\text {st }} 24$ hours due to cardiac problem either dysrhythmias or cardiogenic shock, metabolic acidosis was also a precipitating factor of death, So early detection of cardiac disorders and proper management of arrhythmias may reduce mortalities. The high mortality rate in our study may be explained by absence of a tertiary specialized centre to deal with these patients in Fayoum governorate, bad facilities present in the hospital in which the study done, no protocol of treatment for such cases and inexperience of the ICU team and there is no protocol for management of such cases.

The normal time interim between ingestion of aluminum phosphide and demise is three hours with a scope of 1-48 hours, $95 \%$ of the patients die inside 24 hours and the commonest reason for death in this gathering is arrhythmia. Passing following 24 hours is because of shock, acidosis, ARDS and arrhythmia. The death rate is exceptionally factor, extending from $37-100 \%$ and can achieve over $60 \%$ even in experienced and very much prepared centers (Wahab et al., 2009).

\section{CONCLUSION}

Aluminum phosphide is a highly toxic pesticide, which is cheap, easily available and present anywhere in Egypt. 60 patients were enrolled in the study, 49 were males and 11 females. The commonest symptoms were hypotension, cardiogenic shock and palpitation which presented as $83 \%, 80 \%$ and $70 \%$ respectively. $90 \%$ of patients had abnormal ECG findings and metabolic acidosis was detected in $72 \%$ of patients. The mortality rate in the current study was $92 \%$. Cardiogenic shock, ECG arrhythmias and metabolic acidosis are poor prognostic criteria for the outcome of toxicity of ALP.

Recommendations: we recommend that

1- ALP tablets use should be restricted and regulated by ministry of health.

2- Mass media education of the public for the dangers of this pesticide.

3- Establishing a poison control center to serve the people of Fayoum governorate and a protocol for management of such cases of poisoning should be available for Fayoum general hospital physicians.

4- Finding a suitable and safe alternative to human health through continuous scientific research.

- Conflict of interest: none.

- This research did not receive any specific grant from funding agencies in the public, commercial, or not-for-profit sectors.

\section{REFERENCES}

Akkaoui M, Achour S, Abidi K, Himdi B, Madani A and Zeggwagh AA. (2007): Reversible myocardial injury associated with aluminum phosphide poisoning. Clin Toxicol (Phila), 45:728-31.

Anand R, Sharma DR, Verma D, Bhalla A, Gill KD and Singh S. (2013): Mitochondrial electron transport chain complexes, catalase and markers of oxidative stress in platelets of patients with severe aluminum phosphide poisoning. Hum Exp Toxicol, 32:807-16.

Anger F, Paysant F, Brousse F, Le Normand I, Develay P, Galliard Y, Baert A, Le Gueut MA, Pepin G and Anger JP. (2000): Fatal aluminum phosphide poisoning. $\mathrm{J}$ Anal Toxicol, 24:90- 2.

Bajpai SR. (2010): Aluminium phosphide poisoning: management and prevention. J Indian Acad Forensic Med, 32:352-354. 
Bumbrah GS, Krishan K, Kanchan T, Sharma M, Sodhi GS. (2012): Phosphide poisoning: a review of literature. Forensic Sci Int, 214:1-6.

Burnett RW, Covington AK, Andersen NF, Külpmann WR, Lewenstam AJ, et al., (2000): Use of ion-selective electrodes for blood-electrolyte analysis. Clin Chem Lab Med, 38(4):363-370.

Erfantalab P, Soltaninejad K, Shadnia S, Zamani $N$ and Moghaddam H. (2017): Trend of blood lactate level in acute aluminum phosphide poisoning. World J Emerg Med, $8(2): 116-120$

Ferrer MI, Alvarez Li F and Cepero RA. (2009): Suicide by ingestion of aluminum phosphide: a case report. Emergencias, 21:228-231.

Gurjar M, Baronia AK, Azim A and Sharma K. (2011): Managing aluminum phosphide poisonings. J Emerg Trauma Shock, 4:378-84.

Hosseinian A, Pakravan N, Rafiei $A$ and Feyzbakhsh SM. (2011): Aluminum phosphide poisoning known as rice tablet: A common toxicity in North Iran. Indian J Med

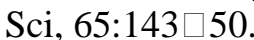

Hsu CH, Chi BC, Liu MY, Li JH, Chen CJ and Chen RY. (2002): Phosphine induced oxidative damage in rats: Role of glutathione. Toxicology, 179:1-8.

Kalawat S, Thakur V, Thakur A and Punjabi ND. (2016): Cardiovascular profile of aluminium phosphide poisoning and its clinical significance. Int J Adv Med, 3:859-64.

Karami S, Jafari A, Abdollahi M. (2013): Comprehensive review of the mechanistic approach and related therapies to cardiovascular effects of aluminum phosphide. Int J Pharmacol, 9:493-500.

Louriz M, Dendane T, Abidi K, Madani N, Abouqal $R$ and Zeggwagh AA. (2009): Prognostic factors of acute aluminum phosphide poisoning. Indian $\mathrm{J}$ Med Sci, 63:227-34.

Maitai C, Njoroge D, Abuga K, Mwaura A and Munenge R. (2004): of possible antidotal effects of activated charcoal, sodium bicarbonate, hydrogen peroxide and potassium permanganate in zinc phosphide poisoning. East Central Afr J Pharm Sci, 5:38-41.

Mathai A and Bhanu MS. (2010): Acute aluminium phosphide poisoning: Can we predict mortality? Indian J Anaesth, 54:302-7.

Moghaddam $H$ and Zamani N. (2016): Therapeutic role of hyperinsulinemia/euglycemia in aluminum phosphide poisoning. Medicine, 95(31):e4349.
Mohajeri SK, Jafari A and Abdollahi M. (2013): comprehensive Review of Mechanistic and Related Therapies to Cardiovascular Effects of Aluminum Phosphide international. journal of pharmacology, (4):1-8.

Raba J, and Mottola HA. (1995): Glucose Oxidase as an Analytical Reagent. Critical Reviews in Analytical Chemistry, 25 (1): 142.

Ram A and Shrivastava SS. (1988): A study of aluminium phosphide poisoning with special reference to therapeutic efficacy of magnesium sulfate. J Asso Physician India, 36(1):23-4.

Ranga GS, Dwivedi S, Agarwal $M$ and Kumar D. (2004): Aluminium phosphide poisoning in a young adult: a suicidal cardiotoxin simulating myocardial ischaemia. J Ind Acad Clin Med, 5:369.

Saidi H and Shojaie S. (2012): Effect of sweet almond oil on survival rate and plasma cholinesterase activity of aluminum phosphideintoxicated rats. Hum Exp Toxicol, 31:518- 22.

Sepaha GC, Bharani A and Jain SM. (1985): Acute ALP poisoning J. Indian Med Ass, 83:378.

Shadnia S, Rahimi M, Pajoumand A, Rasouli MH and Abdollahi M. (2005): Successful treatment of acute aluminium phosphide poisoning: possible benefit of coconut oil. Hum Exp Toxicol, 24:215-8.

Singh S, Dilwari B and Vashist R. (1985): Aluminium phosphide ingestion. $\mathrm{Br}$ Med $\mathrm{J}$, 290: 1110-1111.

Sudakin D. (2005): Occupational exposure to aluminium phosphide and phosphine gas? A suspected case report and review of the literature. Hum Exp Toxicol, 24:27-33.

Taromsari MR, Shad B, Nargesi DA, Akhoundzadeh N and Karkan MF. (2011): The Study of Various Cardiac Arrhythmias in Patients Poisoned With Aluminum Phosphide (Rice Tablet). Ind J Tox, 5:1-2.

Umair Aziz and Amir Husain (2015): Frequency of Cardiac Arrhythmias in Patients with Aluminum Phosphide Poisoning. Asia Pacific journal of Medical Toxicology, 4:147150.

Wahab A, Rabbani MU, Wahab S and Khan RA. (2009): Spontaneous self ignition in a case of acute aluminium phosphide poisoning. Am J Emerg Med, 27:752-756.

Wahab A, Zaheer MS, Wahab S and Khan RA. (2008): Acute aluminium phosphide poisoning: an update. Hong Kong J Emerg Med, 15:152-5. 


\section{نتائج السمية ومتوسطات الوفيات من التسمم بفوسفيد الألومنيوم

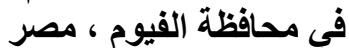

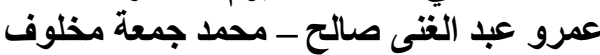 \\ قسم الطب الثرعى و السموم الإكلينيكية ـ كلية الطب - جامعة الفيوم}

مقدمة البحث: فوسفيد الألومنيوم هو مبيد حشري صلب مثالي لأنه رخيص وفعال وسهل الاستخدام ، على شكل أقر اص بيضاء

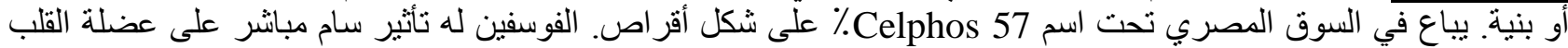

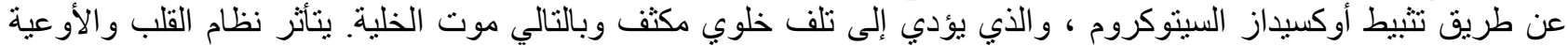

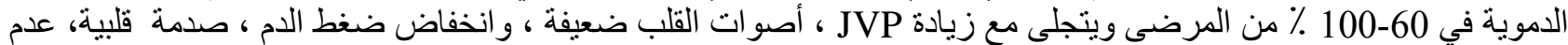
انتظام ضربات القلب ، التهاب عضلة القب القب و التهاب التهاب التامور.

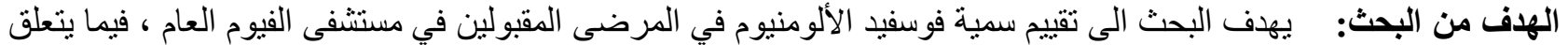

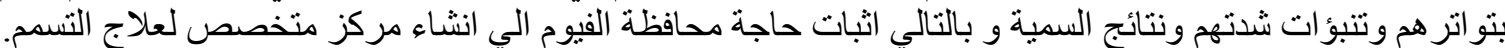

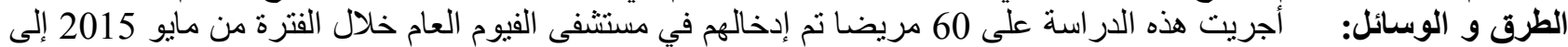

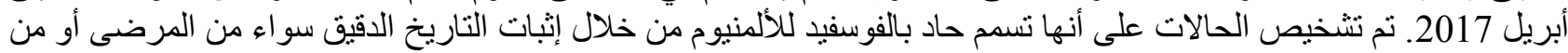

ذويهم.

و قد شملت هذه الدر اسة: 1. البيانات الديمغر افية الاجتماعية : وتثنمل البيانات المتعلقة بالعمر و الجنس. 2. 3. الفحص السريرى: نتائج الفحص العام والفحص التفصيلى الذيى تضمن الجهاز التنفسي، الجهاز القلبي الوعائي، الجهاز العصبي و الفئ تص الام الثرياني ونسبة السكر العشو ائى في الدم وقياس الصو ديو م والبو تاسيوم و قياس أنزيمات الفحو صاز المعندي المعوية. قباني.

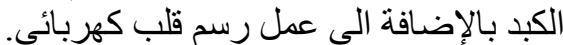

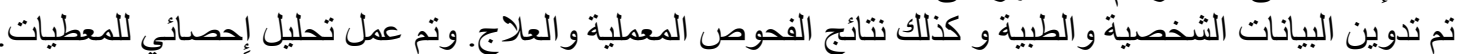

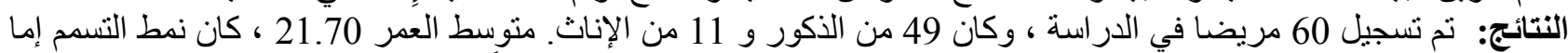

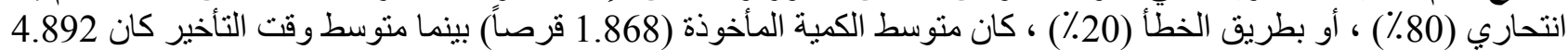

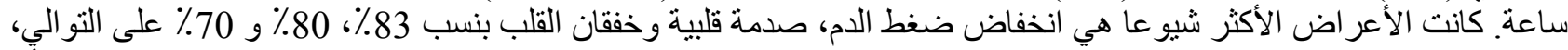

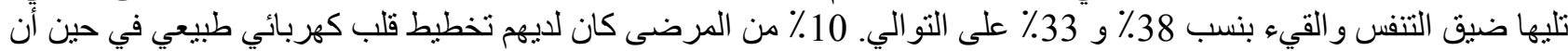

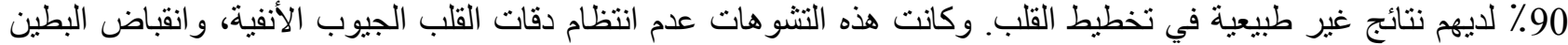

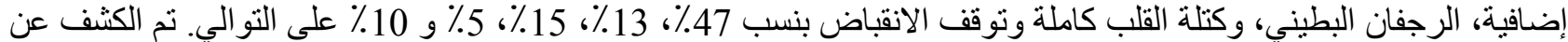

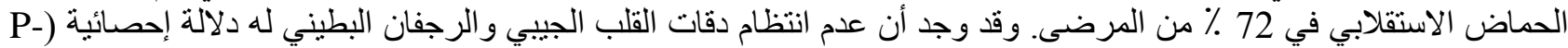

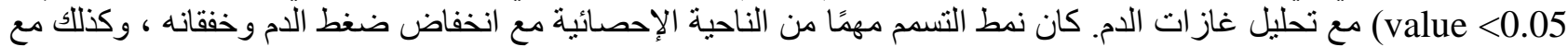

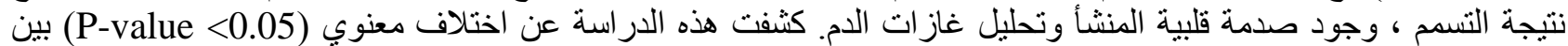

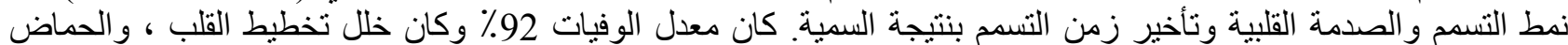

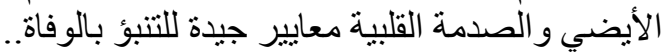
التوصيات: توصي الدر اسة بالاتي:

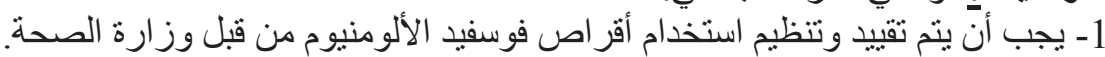

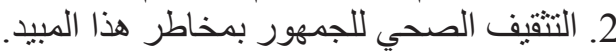
3- إنشاء مركز للككافحة السموم لخدمة أهالي محافظة الفيوم.ويجب أنساء يكون هنالك بروتوكول مناحاً لأطباء مستشفى الفيوم العام

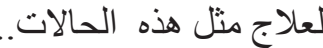
4- إيجاد بديل مناسب و آمن للصحة البشرية من خلال البحث العلمي المستمر. 